UDC 94(470+571)“17/1917”

Submitted: 03.08.2017

LBC 63.3(2Poc-4Act) 534

Accepted: 17.11.2017

\title{
FOREIGN WAR PRISONERS IN THE ASTRAKHAN PROVINCE IN THE YEARS OF THE FIRST WORLD WAR AND THE RUSSIAN REVOLUTION
}

\author{
Elena G. Timofeeva \\ Astrakhan State University, Astrakhan, Russian Federation \\ Sergey V. Lebedev \\ Astrakhan State University, Astrakhan, Russian Federation
}

Elena Yu. Bolotova

Volgograd State Socio-Pedagogical University, Volgograd, Russian Federation

\begin{abstract}
The article is devoted to the study of various aspects of military captivity, which became a mass phenomenon ("mass experience") in the years of the First World War and the revolutionary events in Russia and which influenced both the individual fate of war prisoners and different sides of the development of society. The article presents data on the number of war prisoners located in the years of war and revolution on the territory of the Astrakhan province, their categories and ethnic composition. The majority of war prisoners were soldiers of the German, Austro-Hungarian armies. The largest number of war prisoners on the territory of the province was recorded in May 1918. On the basis of documentary material, most of which is first introduced in the scientific use, the war prisoners' accommodation, provision of clothing, food, medical care is researched. The placement of the contingent of war prisoners and their number depended on the needs of the region in labour force. War prisoners were sent to work on the municipal facilities in the provincial center and district towns, were attached to joint-stock and private enterprises, worked as doctors and paramedics in hospitals.

The situation of war prisoners fully depended on socio-economic and political situation in the country. The problems of supply of war prisoners with clothing and food aggravated with the economic and political crisis in the country as well as rising prices and were common to all categories of population who needed support. The deterioration of living conditions led to increase in diseases, epidemics and deaths among the prisoners. Local authorities made efforts to supply war prisoners with food and provide with higher wages and hospitals. After the events of February 1917 there were hopes for mitigation of the regime of war prisoners, but visible improvement did not follow and the weakening supervision of war prisoners resulted in the growth of prison breaks.

Key words: the First World War, Astrakhan province, war prisoners, camp for war prisoners, revolution, hospital, epidemic, food issue.

Citation. Timofeeva E.G., Lebedev S.V., Bolotova E.Yu. Foreign War Prisoners in the Astrakhan Province in the Years of the First World War and the Russian Revolution. Vestnik Volgogradskogo gosudarstvennogo universiteta. Serija 4, Istorija. Regionovedenie. Mezhdunarodnye otnoshenija [Science Journal of Volgograd State University. History. Area Studies. International Relations], 2017, vol. 22, no. 6, pp. 110-121. (in Russian). DOI: https://doi.org/10.15688/jvolsu4.2017.6.11

\section{ИНОСТРАННЫЕ ВОЕННОПЛЕННЫЕ НА ТЕРРИТОРИИ АСТРАХАНСКОЙ ГУБЕРНИИ В ГОДЫ ПЕРВОЙ МИРОВОЙ ВОЙНЫ И РОССИЙСКОЙ РЕВОЛЮЦИИ}

\author{
Елена Георгиевна Тимофеева
}

Астраханский государственный университет, г. Астрахань, Российская Федерация 
Сергей Владиславович Лебедев

Астраханский государственный университет, г. Астрахань, Российская Федерация

\section{Елена Юрьевна Болотова}

Волгоградский государственный социально-педагогический университет, г. Волгоград, Российская Федерация

Аннотация. Статья посвящена исследованию различных аспектов военного плена, ставшего в годы Первой мировой войны и революционных событий в России массовым явлением («массовым опытом») и оказавшим влияние как на индивидуальные судьбы военнопленных, так и на различные стороны развития общества. В статье приводятся данные о количестве военнопленных, размещенных в разные годы войны и революции на территории Астраханской губернии, их категориях и национальном составе. Большинство военнопленных составляли военнослужащие германской, австро-венгерской армий. Документы зафиксировали самую большую численность военнопленных на территории губернии в мае 1918 года. На основе документального материала, большинство из которого впервые вводится в научный оборот, исследуется система содержания военнопленных, условия их размещения, снабжения одеждой, продуктами питания, медицинского обслуживания. Места размещения контингента военнопленных и их количество зависели от потребности региона в рабочей силе. Военнопленные направлялись на работы на объекты городского хозяйства в губернском центре и уездных городах, прикреплялись к акционерным и частным предприятиям, работали врачами и фельдшерами в госпиталях.

Положение военнопленных в полной мере зависело от социально-экономической и политической обстановки в стране. Проблемы снабжения военнопленных одеждой, продуктами питания обострялись по мере углубления экономического и политического кризиса в стране, дороговизны и были общими для всех категорий населения, нуждающихся в поддержке. Ухудшение условий жизни приводило к росту заболеваемости, эпидемиям и смертности среди военнопленных. Местная власть прилагала усилия для обеспечения военнопленных продовольствием, повышения заработной платы, организации лазаретов. После февральских событий 1917 г. были надежды на смягчение режима содержания военнопленных, однако заметного улучшения положения не последовало, а ослабление надзора над военнопленными приводило к росту их бегства.

Представленный в статье материал является результатом совместной работы авторов: С.В. Лебедевым была проведена работа по выявлению, систематизации документального материала, анализу количественных характеристик иностранных военнопленных; Е.Г. Тимофеева обобщила материал об использовании труда военнопленных, их социальном положении и санитарно-медицинской помощи; Е.Ю. Болотовой рассмотрен вопрос о влиянии экономического кризиса на положение пленных, проведена работа по структурированию статьи и подготовке ее к публикации.

Ключевые слова: Первая мировая война, Астраханская губерния, военнопленные, лагерь для военнопленных, революция, лазарет, эпидемия, продовольственный вопрос.

Цитирование. Тимофеева Е. Г., Лебедев С. В., Болотова Е. Ю. Иностранные военнопленные на территории Астраханской губернии в годы Первой мировой войны и Российской революции // Вестник Волгоградского государственного университета. Серия 4, История. Регионоведение. Международные отношения. 2017. - T. 22, № 6. -C. 110-121. - DOI: https://doi.org/10.15688/jvolsu4.2017.6.11

Астраханская губерния входила наряду с Вятской, Казанской, Пензенской, Пермской, Самарской, Саратовской, Симбирской, Оренбургской, Уфимской, а также Уральской и Тургайской областями в состав Казанского военного округа.

Во время Первой мировой войны на территории округа находилось 285376 военнопленных [22, с. 91-92], составивших особую социальную группу. В ее состав входили: захваченные в плен в ходе боевых операций военнослужащие армий, противостоящих России в войне государств; состоящие на действительной военной службе или в запасе подданные Германии и Австро-Венгрии; германские и австрийские подданные мужского пола в возрасте 18-45 лет.

Количество военнопленных, размещенных на территории Астраханской губернии, постоянно менялось, поскольку прибывавших в конкретный населенный пункт военнопленных затем переправляли в другие места [23, с. 571, $572,841]$. Состояние архивных фондов не позволяет точно проследить изменение числен- 


\section{ОТЕЧЕСТВЕННАЯ ИСТОРИЯ}

ности военнопленных. Первые пленные (611 человек) прибыли в Астрахань спустя месяц после начала войны [3]. В январе 1916 г. в губернском центре размещалось 270 офицеров и 3950 нижних чинов [25, л. 5]. После Февральской революции численность контингента «узников войны» значительно не изменилась. На 6 апреля 1917 г. в Астрахани находились 10 офицеров и 299 солдат германской армии, 7 штаб-офицеров, 478 офицеров, 2927 солдат австрийской армии, 21 офицер и 120 солдат турецкой армии [28, с. 187]. В октябре 1917 г. нижних чинов насчитывалось 4315 человек, офицеров - 375 человек, в конце ноября 1917 г. соответственно 2200 и 282 человека [32, с. 187]. Величина контингента военнопленных менялась в основном в зависимости от потребности региона в рабочей силе. Основываясь на архивных документах, можно утверждать, что максимальное количество пленных, размещенных в Астраханской губернии, приходится на май 1918 г.: 319 офицеров и 10584 рядовых, что составило 3,8 \% общего количества военнопленных, находившихся в Казанском военном округе [20, л. 9 об., 14].

Помимо губернского центра, пленных размещали в уездных городах Енотаевске, Черном Яру, Цареве. Так, например, на 1 января 1916 г. в Енотаевске находилось 20 офицеров и 643 человек нижних чинов, в Черном Яру соответственно 44 и 1165 человек, в Цареве -25 и 212. Абсолютное большинство составляли военнослужащие австро-венгерской армии - 69 офицеров и 1640 рядовых [23, c. 841]. Спустя два года, в феврале 1918 г., на работах было занято в Енотаевске - 470 нижних чинов австро-венгерской армии, в Цареве - 2 672, в Черном Яру - 240 солдат германской и 1525 австро-венгерской армий. В марте того же года их численность изменилась: в Енотаевске - 37 офицеров (1 немецкий офицер и 36 - австрийских) и 156 рядовых, в Цареве - 390 солдат, из них 2 - турок, в Черном Яру - 824 солдата [20, л. 5-6].

Контроль за военнопленными осуществлял штаб Казанского военного округа, а непосредственно в Астраханской губернии содержанием и размещением «узников воны» занимались губернские и городские власти.
Рядовых расселяли по казармам, ночлежкам, офицеров - в гостиницах и частных домах. Увеличение численности военнопленных вынуждало астраханские власти построить в 1915 г. специальный лагерь в Болдинской степи недалеко от железнодорожного вокзала. Для размещения пленных использовались также помещения на территории бывшего пивоваренного завода «Богемия», получившие известность как лагерь «Богемия». В последующие годы в связи с увеличением количества пленных создавались новые лагеря. Надзор над военнопленными осуществляли «особо нанимаемые в достаточном количестве» вооруженные десятники и сторожа. На полицию было возложено общее руководство охраной [32, с. 186-187].

Документы позволяют в подробностях воссоздать условия проживания военнопленных. В них отмечается, что помещения казарм были грязными и тесными, пленным досаждало огромное количество вшей и блох. Спать приходилось на нарах в два ряда, прикрываясь мешками с соломой. В казармах недостаточно поддерживалась чистота, отравляло нахождение военнопленных в лагерях и зловоние выгребных ям. Лагеря обслуживались самими военнопленными, пленные сами стирали белье. Представители местной власти предпринимали попытки исправления ситуации, однако затянувшаяся изнурительная война отнимала все больше сил и средств для решения сложных задач военного времени [24, л. $825 ;$ 34, л. 59-59 об.].

Согласно V статье Гаагской конвенции, «свобода военнопленных не должна подвергаться излишним стеснениям, заключение применяется к ним лишь в виде исключительной временной меры». Однако на местах расположения военнопленных это правило нарушалось. Лагеря для военнопленных ограждались проволочными заграждениями. Постоянный надзор за военнопленными осуществляли часовые, караульные и надзиратели. Впоследствии у многих пленных, как пишет Н.Е. Журбина, появился особый вид душевного расстройства «психоз колючей проволоки» [6, с. 231]. Не в лучшем положении находились военнопленные, размещенные в частных домах. Так, например, комиссия санитарного отдела Астраханского губернского правления в марте 1916 г. отмеча- 
ла, что «в пекарне Федорова - в трех квартирах тесно... и мало света» [12, с. 91].

Труд «узников войны» использовался как местными властями, так и частными лицами. Они работали на городских предприятиях (городской ассенизационный обоз, строительство городской электростанции), мостили улицы, строили дороги и городскую канализацию, очищали водостоки, сооружали валы для защиты города от наводнений, привлекались для уборки урожая [29, с. 61-72]. Заведование работами возлагалось на городское общественное управление губернского центра и уездных городов, а также уездные земские управы.

В 1917 г. на городских работах было занято более 1000 военнопленных. Из них на канализационных работах состояло 425 человек, на дорожных - 60, в хлебопекарнях - 15, при городских огородах - 28, при ассенизационном обозе - 156 пленных [34, л. 108-111, 118]. Военнопленные были прикреплены к различным заведениям и обществам, среди которых Союз помощи больным и раненым воинам, часовая мастерская Фишкина, акционерное общество «Астраханский холодильник», Комитет Марии Павловны и др., причем часть военнопленных трудилась без разрешения штаба округа [23, с. 583-584]. В меньшем количестве военнопленные трудились и на предприятиях, работавших на оборону: например, на Паробичевом бугре в домах Лепехина - 1 , Потокина - 2, Алисанова - 2, Маковецкого 13 , Колесова - 2, Михальченко - 3, Красильникова -8 , Захарова - 26 и др. - всего 62 человека. 14 военнопленных трудились на заводе по производству консервов [33, л. 11, 14]. Несмотря на запреты использовать военнопленных в качестве домашней прислуги, у проживающего в районе астраханских боен инженера Немечек в услужении находились трое военнопленных, «лично ему отпущенных»: кучер, повар и домашний портной [14, л. 167].

Согласно утвержденному «Положению о военнопленных» от 7 октября 1914 г., с пленными следовало обращаться «человеколюбиво», обеспечивая питанием, одеждой и обувью, правом получать деньги, письма, посылки с родины. Пленным полагалось выделять две смены белья в год, верхнюю одежду и обувь выдавали на год по мере надобности (вместо сапог допускалась выдача башмаков, ботинок, даже лаптей «за уменьшенную плату») [34, л. 19]. Городская управа выделяла средства на ремонт одежды военнопленных. Расписки старших в группе пленных, обслуживавших канализацию, свидетельствуют о том, что капрал Бердяньи Дезидериус получил 16 руб. 75 коп. на покупку ниток, иголок, пуговиц для «...починки одежды, мундиров, сорочки и кальсон» для военнопленных нижних чинов, трудившихся на городском лесопильном заводе с 15 августа 1916 г. по 17 июня 1917 года. Фельдфебель лагеря «Казарова» Василь Монцибовия получил 18 руб. 78 коп. на эти же цели и на покупку «сапожного доклада» (дратва, деревянные гвозди, щетина, чернила, воск и т. д.) для «... .ородских резервных сапог». Фельдфебель лагеря «Богемия» Отто Вальтер расписался в получении на покупку «сапожного доклада» 69 руб. 34 коп. за июнь 1917 г.; 30 руб. 19 коп. - за покупку ниток, пуговиц в период с 13 сентября по 31 декабря 1916 г., 20 руб. 40 коп. - с 1 января по 30 июня 1917 года. Рабочий Полони Бэла получил 20 руб. за шинель, сгоревшую во время вспышки мазута на паровом копре на насосной станции 28 июля 1917 г. [26, л. 97, 141, 142 , $148,150,151,174]$.

Питание военнопленных также было организовано в соответствии с требованиями «Положения о военнопленных»: рядовые пленные получали «кормовые деньги и продовольствие в натуре» на одинаковом основании с солдатами российской армии [5, с. 260]. В Астраханской губернии военнопленные нижних чинов довольствовались нормами питания русских солдат: 3 фунта хлеба, 1/2 фунта мяса, 32 золотника крупы, чай с сахаром.

В условиях продолжающейся войны, по мере углубления экономического кризиса ситуация с обеспечением пленных продовольствием ухудшалась. Летом 1915 г. астраханский губернатор Соколовский уведомил о сокращении принятых норм: 2 фунта хлеба, 24 золотника крупы, мясной паек уменьшился до 1/4 фунта (баранина, свинина или рыба), 2,5 коп. давали «за все приварочные припасы». Обязательным условием являлось соблюдение два раза в неделю постных дней. Была отменена выдача 15 копеек в месяц на человека на хозяйственные надобности и на «чайное довольствие» $[15$, л. 136, 144]. 


\section{ОТЕЧЕСТВЕННАЯ ИСТОРИЯ}

В 1917 г. поразивший все стороны губернской жизни системный кризис - продовольственный, финансовый, политический - привел к обострению ситуации с обеспечением продовольствием, одеждой и обувью наиболее социально незащищенных слоев населения, среди которых оказались и военнопленные. Остановить рост цен на товары первой необходимости, превосходящий по своим размерам рост цен на аналогичные товары в соседних губерниях, власти не удавалось. В Астраханской губернии с декабря 1915 г. по июнь 1917 г. стоимость пшеничной муки возросла на $96,3 \%$, ржаной муки - на 161,5\%, сахара на $37,6 \%$, соли - на 24,7 \%, мыла - на 155,6 \%, керосина - на $45,6 \%$, яиц - на $80 \%$, молока на $50 \%[11$, с. 223$]$.

В январе 1917 г. последовал запрет продавать военнопленным офицерам и нижним чинам продукты, это могли осуществлять только специально назначенные лица. Среди пленных назначался «старший» (по преимуществу унтер-офицер или фельдфебель), который закупал продукты на рынках города для общего обеспечения («артелью») пленных рабочих. Так, для работавших на электростанции пленных, покупкой провизии для кухни занимался фельдфебель австрийских войск Адольф Фуртнер [16, л. 74].

Если учесть, что военнопленные нижние чины тратили заработанные на поденной работе деньги на усиление своего питания, углубление кризиса продовольствия в России вообще и в городе в частности делало их существование тягостным. Так, например, рабочие-военнопленные Дорожного отдела сообщили в Управу, что «...вынуждены покупать продовольствиена базарах по тройным ценам». Отсутствие «калача» принуждало их есть овощи. Кроме продовольствия, нужны были одежда, обувь, белье, мыло, махорка и спички, но купить эти продукты у них не было возможности [15, л. 240].

В условиях углубляющегося кризиса местные власти пытались изыскивать средства на покупку продуктов питания для военнопленных. В конце февраля 1917 г. поступило ходатайство отдела управы по расширению и переустройству городской электростанции о том, чтобы отпустить «для нужд рабочих военнопленных» 50 пудов капусты и 40 пудов картофеля. 50 пудов «рубленой» капусты выделили, а вот в картофеле для военнопленных было отказано «за недостатком» его [7, с. 52-54].

С 16 по 30 мая 1917 г. на продовольствие занятых на канализационных работах пленных, находившихся в «лагерях “Богемия", Казарова и Болдинской лесопилки», городские власти израсходовали 770 рублей. От председателя канализационной комиссии И.А. Бирюкова в лагерях «Богемия» и Казарова на продовольствие 245 человек в период с 11 по 15 июля 1917 г. было получено 796 руб. 25 коп. $[26$, л. 32, 90].

Ухудшение условий жизни, рост цен на продовольствие вынуждали военнопленных обращаться к местным властям с просьбой о повышении оплаты труда. В апреле 1917 г. в Городскую управу поступила докладная записка от работавших на электростанции военнопленных, где они просили об увеличении зарплаты. Чернорабочие получали по 95 коп., чертежники и табельщики - 1 руб. 35 коп., столяр - от 95 коп. до 1 руб. 05 копеек. Работая на предприятии два года, они ни разу не получали «никакой прибавки» и вынуждены были бороться «с невыносимыми условиями дороговизны настоящего времени». За эти суммы нужно было не только «продовольствоваться», но и «удерживать» одежду в «пригодном виде». В воскресные и праздничные дни, в период болезни «жалование не причиталось». Для продовольствия каждый пленный получал только 40 коп. в день. Просили увеличить плату для чернорабочих до 2 руб., для фельдшеpa, исполнявшего обязанности врача, - до 3 руб. 50 копеек. В дни болезни и другие нерабочие дни выдавать по 1 руб. в день. Расчет был следующий: на приготовление завтрака -4 коп., обеда -35 коп., ужина - 25 коп., чая - 4 коп., на 2,5 фунта хлеба - 30 копеек. Они просили об установлении одинаковой поденной платы для всех, кто работал на городских предприятиях [4, л. 215-218].

Чернорабочие, проживающие в лагерях, стали получать от 8 до 11,5 руб.: работающие на электростанции - 11 руб., на канализационных работах - 11,5 руб., на водопроводе 10,5 руб., кузнецы и слесари получали от 9 до 12,5 руб., в рабочем обозе $-8-8,5$ рублей. Фельдшеру платили 12,5 рублей. Прожиточный минимум для военнопленного в Астрахани в декабре 1917 г. равнялся 2 руб. 10 коп. в 
день. Один рубль в сутки выплачивался больным военнопленным, столько же полагалось в праздничные дни. Спустя год, в условиях роста дороговизны Управа признала плату пленным «ничтожной», повысив ее в январе 1918 г. на 50 копеек. В апреле надбавка составила еще 1 руб. 50 коп., также было увеличено содержание больным до 2 руб. 50 коп. в день [15, л. 229-229 об, 239].

Заботой местных властей стала организация медико-санитарной помощи пленным: лечение раненых и больных, проведение противоэпидемиологических мероприятий.

В ходе мобилизации на фронт попали многие земские врачи и фельдшеры, из-за чего на 1 сентября 1915 г. нехватка врачей в городах и уездах Астраханской губернии составила, по данным земского союза, более $44 \%$. К концу 1915 г. вакантными оставались 48 \% врачебных должностей и $17 \%$ фельдшерских должностей [1, с. 233]. Острая потребность в специалистах потребовала привлечения труда военнопленных врачей, младшего медицинского персонала. Так, например, в распоряжении Астраханского уездного воинского начальства на 1 сентября 1917 г. находилось 14 военнопленных врачей и «студентов-медиков» австрийской и германской армий (семеро немцев, двое румын, трое мадьяр, серб и чех). При городском военном госпитале состояли два врача-австрийца, которые там же и проживали. В октябре 1917 г. уполномоченный Датского посольства в Петрограде Рендторф обратился в штаб округа с ходатайством о разрешении военнопленному фельдшеру Станиславу Шадеку работать в датском госпитале для военнообязанных в Астрахани [24, л. 319, 657].

Размещение в регионе тысяч военнопленных приводило к тому, что местные жители оказались ограничены в получении медицинской помощи, так как нуждающиеся в лечении военнопленные занимали в лечебных учреждениях места, предназначенные для лечения астраханцев. Выход из создавшейся ситуации региональные власти видели в создании новых лечебных заведений для военнопленных [5, с. 260]. В апреле 1918 г. городская власть разместила госпиталь в здании Большой Московской гостиницы (дом Смирнова на Большой Демидовской улице). В но- ябре 1918 г. госпиталь перевели в дом Н.В. Серина на набережной р. Кутум. В августе 1918 г. в распоряжение Астраханской краевой комиссии о пленных и беженцах жилищный совет предоставил под лазарет для военнопленных свободные помещения в доме Ахвердова на Полицейской улице. Горсовет спешно изыскивал для этих целей 200 топчанов [8, л. 2, 29; 9, л. $1 ; 10$, л. 2-5].

Затяжной характер войны, тяготы плена не только для находившихся в лучших условиях офицеров, но и для солдат проявлялись все отчетливее в психологическом плане. В августе 1917 г. в психиатрическом отделении Астраханской губернской земской больницы находились 13 «душевнобольных» военнопленных австрийской армии [24, л. 116]. Известны и случаи самоубийств. Так, в феврале 1917 г. в доме Буракова на Эллинге обнаружили труп повесившегося 26-летнего австрийского офицера Т. Меаниковича [13, л. 43].

Долгое пребывание в плену не могло не сказаться на военнопленных. В конце 1916 г. был составлен список болезней, дававших пленному право быть интернированным в нейтральные страны. Офицеры писали заявления на медицинское освидетельствование, чтобы их признали инвалидами или полуинвалидами для отправки в эти страны. Такие комиссии создавали и в Астрахани, по их заключению многих пленных по состоянию здоровья отправляли на общий сборный пункт в Москву для последующего интернирования [34, л. 126].

Офицеры австрийской армии, размещенные в здании 5-го городского училища, осенью 1917 г. в своих прошениях указывали на разные заболевания. Иван Подарну, находившийся в плену два с половиной года, «страдал сильной сердечной болезнью». Ян Фридрих, пребывавший в плену с 15 января 1915 г., жаловался на «острое малокровие и порок сердца». И. Шаравец страдал от «глухоты на оба уха». И. Пако, признанный инвалидом по причине «тяжелой глазной болезни» еще в Перми и назначенный для отправки в Австрию, был почему-то перемещен в Астрахань («по неизвестным причинам»). Здесь ему назначили вторичное медицинское освидетельствование для причисления к категории полуинвалидов и интернирования в нейтральные страны. В конце августа 1917 г. начальнику 


\section{ОТЕЧЕСТВЕННАЯ ИСТОРИЯ}

Московского окружного эвакуационного пункта сообщили об отправке из Астрахани одного военнопленного врача-инвалида (австрийца А. Фишера), семи офицеров, подлежавших интернированию. Трех военнопленных офицеров австрийской армии отправили 27 сентября 1917 г. в Симбирский Завольский лагерь согласно достигнутому соглашению об интернировании в Швецию 500 военнопленных офицеров австрийской армии из России. В Казань препроводили трех турок-инвалидов. В это же время к интернированию в нейтральные страны были определены 88 военнопленных нижних чинов. Этот же процесс продолжался и в последующее время [24, л. 304, 373-374, 378, $380,401-402,564,583,591,607,788]$.

Массовый приток военнопленных осложнил эпидемическую ситуацию в Астраханской губернии. Среди болезней, поражавших военнопленных, лидировал сыпной тиф, что объяснялось условиями содержания, истощением организма «узников войны». В мае 1915 г. вспышка тифа была в лагере военнопленных «Богемия» $[18$, л. 82], в декабре 1915 г. зафиксировали 32 случая заболевания сыпным тифом среди пленных в Царевском уезде Астраханской губернии, в июле 1916 г. тифом в Астрахани болели 87 военнопленных [21, л. 123].

Резкое ухудшение санитарно-эпидемиологической ситуации в период революционных потрясений привело к увеличению заболеваний и смертности, к тому же сказывались долгие годы плена, голодная пора революционного периода. В феврале 1917 г. в Астрахани среди 3952 военнопленных нижних чинов здоровых было 918 человек, только что оправившихся от болезни - 1434 человека, больных 517 человек, «цынготных» - 510 человек [30, c. 188]. В марте 1917 г. из 4105 военнопленных здоровых солдат было лишь 298 человек $[19$, л. 113]. Среди военнопленных, находившихся в Астрахани в августе 1917 г., здоровых было 431 человек, «не вполне выздоровевших» - 59 человек, больных - 531 человек, у 60 пленных выявлена цинга, 85 страдали малярией [24, л. 465]. Увеличилась смертность: за 1918 г. умерло 54 человека: от холеры -4 , от тифа -9 , от воспаления легких -28 , от туберкулеза - 7, от сердечно-сосудистых заболеваний - 6. В период весны - осени
1919 г. умерло 97 человек, большинство от сыпного тифа [17, л. 10-76].

Февральская революция вызвала надежды на послабление режима в отношении военнопленных. Так, например, им было разрешено вступать в брак с местным населением. Это побудило военнопленных обращаться с ходатайствами о браке и улучшении жилищных условий. В августе 1917 г. военнопленный Георг Пецарский подал прошение начальнику лагеря военнопленных выдать ему удостоверение, подтверждающее его происхождение («из сербов») и вероисповедание («православного»). Удостоверение необходимо было для получения разрешения на брак с правом жить в частной квартире и заниматься трудовой деятельностью в соответствии с профессией (занимался «парикмахерством») [24, л. 613].

Местные власти не уделяли должного внимания к осуществлению контроля за действиями военнопленных. Весной 1917 г. они свободно гуляли, посещали общественные и увеселительные места. В октябре 1917 г. неоднократно задерживали военнопленного австрийской армии А. Венгера за то, что в одной из городских квартир он переодевался и без формы, в «вольной» (гражданской) одежде, гулял ночами по Астрахани. Однако о существенном изменении и улучшении положения военнопленных говорить нет оснований.

Ослабление надзора способствовало росту числа побегов среди военнопленных. По данным астраханской городской милиции, за июль - август 1917 г. из г. Астрахани бежало 272 человека. В основном пленные бежали с городской электростанции, из анонимного общества «Астраханские рельсовые пути», акционерного общества «Астраханский холодильник» и с некоторых других предприятий [31, c. 182].

После выхода России из войны число военнопленных в Астрахани увеличилось, так как губернский центр являлся транзитным пунктом для возвращавшихся на родину пленных. Почти ежедневно весной 1918 г. прибывали эшелоны с пленными солдатами, которых размещали в «казенных бараках». Всего прибыло до 2500 человек. Для размещения военнопленных отвели бараки, занимаемые ранее солдатами 156-го пехотного полка «на Болде» («дальше 
Селенских Исад, за трамвайной линией»). Из 35 бараков семь заняли военнопленные. В остальных бараках предполагали разместить «венгерскую роту» интернационального полка, беженцев и «железный отряд», прибывший из Баку, 3-й Астраханский железнодорожный полк и др. Таким образом, в одном лагере жили иностранные военнопленные, бойцы Красной армии и беженцы [28, с. 206-207].

Созданная после подписания Брестского мирного договора Астраханская краевая коллегия по военнопленным и беженцам проводила работу по возвращению на родину военнопленных, находившихся на территории губернии. Однако вследствие того, что 1919 г. стал годом активных боевых действий на территории Астраханского края, этот процесс был приостановлен. В январе 1920 г. в Астраханской губернии было зафиксировано 2337 пленных [27, л. 88]. В 1920-1921 гг. советским правительством были подписаны многочисленные соглашения о военнопленных, которые способствовали возвращению их на родину. Военнопленные, которые не смогли вернуться в свои государства в 1917-1919 гг., во3вращались в статусе репатриантов [2].

Региональное измерение военного плена в контексте исследуемой темы послужило основанием для следующих выводов и обобщений.

Трудовое использование пленных потребовало мобилизационных усилий местных властей по распределению трудовых ресурсов (дешевой рабочей силы) по важным отраслям экономики Астраханского края, что в определенной мере помогало решать хозяйственные задачи в период острого дефицита рабочей силы в военное и послевоенное время.

Региональноепространство было наполнено различными практиками, связанными с военным пленом, который в период Первой мировой войны не ограничивался пределами лагеря, был заметен как социальный институт. Фронтирная территория, наполненная опытом взаимодействия и взаимовлияния различных культур, во многом объясняла отсутствие враждебного отношения населения к военнопленным.

\section{СПИСОК ЛИТЕРАТУРЫ}

1. Алиева, А. Н. Участие Астраханского земства в оказании помощи беженцам в 1915-1918 гг.
/ А. Н. Алиева // Астраханские краеведческие чтения : сб. ст. / под ред. А. А. Курапова. - Вып. III. Астрахань : Изд-во Сорокина Р.В., 2011. - С. 229-236.

2. Арзамаскин, Ю.Н.Репатриация иностранных военнопленных Первой мировой войны / Ю. Н. Арзамаскин, А. П. Волков // Вестник Екатерининского институга. - 2014. -№2 (26). - С. 80-85.

3. Астраханский листок. - 1914. - № 224. 15 окт.

4. Докладная записка о военнопленных, работающих на городской электростанции // Государственный архив Астраханской области (ГААО). Ф. 94. - Оп. 1. - Т. 4. - Д. 30814.

5. Еремин, И. А. Военнопленные Первой мировой войны в Западной Сибири / И. А. Еремин // Известия Томского политехнического университета. - 2007. - Т. 310, № 1. - С. 259-263.

6. Журбина, Н. Е. Военнопленные Германии на территории России в годы Первой мировой войны (1914-1918 гг.) / Н. Е. Журбина // Вестник ВГУ. Серия «Лингвистика и международная коммуникация». -2008 . - № 2. - С. 23-235.

7. Журнал заседаний Астраханской городской думы. - 1917. - 25 февр.

8. Журнал заседаний Астраханской городской думы от 1 апреля 1918 г. по вопросу содержания помещений гостиницы на Б. Московской дом Смирнова // ГААО. - Ф. 480. - Оп. 1. - Д. 363.

9. Журнал заседаний Астраханской городской думы от 28 августа 1918 г. по вопросу содержания дома Ахвердова во 2 участке отведенного под лазарет для военнопленных // ГААО. - Ф. 480. Оп. 3. - Д. 304.

10. Журнал заседаний Астраханской городской думы от 13 ноября 1918 г. по вопросу об отводе дома Н.В. Серина в 4 участке на Кутуме под лазарет для военнопленных // ГААО. - Ф. 480. - Оп. 3. Д. 345.

11. Котеньков, С. А. Потребительская кооперация Астраханского края в годы Первой мировой войны / С. А. Котеньков, О. Ю. Котенькова // Астраханские краеведческие чтения : сб. ст. / под ред. А. А. Курапова. - Вып. III. - Астрахань : Изд-во Сорокина Р.В., 2011. - С. 223-228.

12. Отчет Врачебного отдела Астраханского губернского правления от 28 марта 1916 г. // Трагедия плена в мировых войнах: политико-правовые, социально-экономические, культурно-коммуникационные аспекты (на материалах Астраханского региона) : сб. ст. и документов. - Ч. 1. - Астрахань : Изд-во Сорокина Р.В., 2015.

13. Переписка Астраханского губернского жандармского управления с Астраханским гражданским губернатором о военнообязанных и военнопленных, проживающих в г. Астрахани // ГААО. Ф. 286. - Оп. 1. - Д. 944. 
14. Переписка Астраханской городской управы с Астраханским гражданским губернатором о присылке военнопленных для проведения канализационных работ // ГААО. -Ф. 94. - Оп. 8. - Д. 569.

15. Переписка Астраханской городской управы с Астраханским гражданским губернатором по вопросу привлечения военнопленных к городским работам // ГААО. - Ф. 94. - Оп. 1. - Т. 4. Д. 31172.

16. Переписка Астраханской городской управы с Астраханским гражданским губернатором по вопросу привлечения военнопленных к работам на городской электростанции // ГААО. - Ф. 94. Оп. 1. - Т. 4. - Д. 30814.

17. Переписка Астраханской губернской канцелярии с Астраханской городской управой по вопросу устройства военнопленных и их имущества // ГААО. - Ф. 396. - Оп. 1. - Д. 3690.

18. Переписка Канцелярии астраханского гражданского губернатора с Астраханской городской управой по вопросу устройства военнопленных // ГААО. - Ф. 1. - Оп. 2. - Д. 1495.

19. Переписка Управления астраханского уездного воинского начальника с Астраханским гражданским губернатором о положении военнопленных // ГААО. - Ф. 700. - Оп. 1. - Д. 114. - Л. 113.

20. Рапорты и ведомости о количестве пленных, находящихся на работах в военных округах // Государственный архив Российской Федерации (ГАРФ). - Ф. 3333. - Оп. 9. - Д. 1.

21. Сведения об оказании помощи беженцам и лицам, пострадавшим от военных действий // ГААО. - Ф. 1. - Оп. 2. - Д. 1437.

22. Семенов, В. Г. Военнопленные на территории Казанского военного округа и Оренбургской губернии на начальном этапе Первой мировой войны (по приказам по Казанскому военному округу за 1914-1915 гг.) / В. Г. Семенов, И. Р. Ягудин // Евразийское ожерелье : альманах Общественного института истории народов Оренбуржья имени Мусы Джалиля. - Вып. 6. - Оренбург : Изд-во ОГПУ, 2005. - С. 91-110.

23. Семенова, Е. Ю. Мировоззрение городского населения Поволжья в годы Первой мировой войны (1914 - начало 1918 гг.): социальный, экономический и политический аспекты / Е. Ю. Семенова. - Самара : АНО «Изд-во СНЦ РАН», 2012. $888 \mathrm{c}$.

24. Списки военнопленных нижних чинов австрийской и германской армий // ГААО. - Ф. 700. Оп. 2. - Д. 157.

25. Справка о военнопленных и военнообязанных за 1916 г. // ГААО. - Ф. 286. - Оп. 1. - Д. 944.

26. Табель на выдачу жалованья военнопленным, работавшим на канализационных работах // ГААО. - Ф. 94. - Оп. 8. - Д. 873.
27. Телеграммы о предоставлении вагонов для перевозки беженцев, военнопленных // ГАРФ. Ф. 3333. - Оп. 4. - Д. 107.

28. Тимофеева, Е. Г. Астрахань в событиях Великой войны, 1914-1918 годы / Е. Г. Тимофеева [и др.]. - Астрахань : Тип. «Нова», 2014. - 300 с.

29. Тимофеева, Е. Г. Использование труда иностранных военнопленных в период Первой мировой войны (на материалах Астраханской губернии) / Е. Г. Тимофеева, С. А. Федин, С. В. Лебедев // Трагедия плена в мировых войнах: политико-правовые, социально-экономические, культурно-коммуникационные аспекты (на материалах Астраханского региона) : сб. ст. и документов. Ч. 1. - Астрахань : Изд-во Сорокина Р.В., 2015. - С. 61-72.

30. Тимофеева, Е. Г. Организация медико-санитарной помощи военнопленным мировых войн в Астраханском крае / Е .Г. Тимофеева, С. В. Лебедев // Известия ВГПУ. - 2016. - № 9-10 (113). С. 187-193.

31. Тюрин, А. О. Охрана и надзор за военнопленными в Астраханском крае в годы мировых войн / А. О. Тюрин // Известия ВГ ПУ. - 2016. - № 910 (113). - С. 179-187.

32. Федин, С. А. Содержание и охрана военнопленных: опыт мировых войн (на материалах Астраханского региона) / С. А. Федин, Е. Г. Тимофеева // Известия ВГПУ. - 2015. - № 6 (101). - С. 186-192.

33. Циркуляры Астраханского губернского комиссара за 1917 г. // ГААО. - Ф. 290. - Оп. 3. Д. 882.

34. Циркуляры Главного управления по делам местного хозяйства о использовании военнопленных // ГААО. - Ф. 94. - Оп. 1. - Т. 8. - Д. 35454.

\section{REFERENCES}

1. Alieva A.N. Uchastie Astrakhanskogo zemstva v okazanii pomoshchi bezhentsam v 19151918 gg. [Participation of the Astrakhan District in Assisting Refugees in 1915-1918]. Kurapov A.A., ed. Astrakhanskie kraevedcheskie chteniya: sb. st. [Astrakhan Readings on Local History: Collection of Articles]. Astrakhan, Izd-vo Sorokina R.V., 2011, pp. 229-236.

2. Arzamaskin Yu.N., Volkov A.P. Repatriatsiya inostrannykh voennoplennykh Pervoy mirovoy voyny [The Repatriation of Foreign War Prisoners in the First World War]. Vestnik Ekaterininskogo institute, 2014, no. 2 (26), pp. 80-85.

3. Astrakhanskiy listok [Astrakhan Leaflet], 1914, no. 224, October, 15.

4. Dokladnaya zapiska o voennoplennykh, rabotayushchikh na gorodskoy elektrostantsii [Memorandum on War Prisoners Working on the City's 
Power Plant]. Gosudarstvennyy arkhiv Astrakhanskoy oblasti [State Archive of Astrakhan Region], F. 94, Op. 1, T. 4, D. 30814.

5. Eremin I.A. Voennoplennye Pervoy mirovoy voyny v Zapadnoy Sibiri [War Prisoners of WWI in Western Siberia]. Izvestiya Tomskogo politekhnicheskogo universiteta [Bulletin of the Tomsk Polytechnic University], 2007, vol. 310, no. 1, pp. 259-263

6. Zhurbina N.E. Voennoplennye Germanii na territorii Rossii v gody Pervoy mirovoy voyny (1914 1918 gg.) [German War Prisoners in Russia During the First World War (1914-1918)]. Vestnik VGU. Seriya "Lingvistika i mezhdunarodnaya kommunikatsiya» [Bulletin of VSU. Series: Linguistics and International Communication], 2008, no. 2, pp. 23-235.

7. Zhurnal zasedaniy Astrakhanskoy gorodskoy dumy [Journal of Meetings of the Astrakhan City Duma], 1917, February, 25.

8. Zhurnal zasedaniy Astrakhanskoy gorodskoy dumy ot 1 aprelya $1918 \mathrm{~g}$. po voprosu soderzhaniya pomeshcheniy gostinitsy na B. Moskovskoy dom Smirnova [Journal of Meetings of the Astrakhan City Duma of April 1, 1918 on the Maintenance of Premises of the Hotel Smirnov House on B. Moskovskaya Street]. Gosudarstvennyy arkhiv Astrakhanskoy oblasti [State Archive of the Astrakhan Region], F. 480, Op. 1, D. 363.

9. Zhurnal zasedaniy Astrakhanskoy gorodskoy dumy ot 28 avgusta 1918 g. po voprosu soderzhaniya doma Akhverdova vo 2 uchastke otvedennogo pod lazaret dlya voennoplennykh [Journal of Meetings of the Astrakhan City Duma of August 28, 1918 on the Maintenance of Akhverdov's House Reserved for a Hospital for War Prisoners in the $2^{\text {nd }}$ District]. Gosudarstvennyy arkhiv Astrakhanskoy oblasti [State Archive of the Astrakhan Region], F. 480, Op. 3, D. 304.

10. Zhurnal zasedaniy Astrakhanskoy gorodskoy dumy ot 13 noyabrya 1918 g. po voprosu ob otvode doma N.V. Serina v 4 uchastke na Kutume pod lazaret dlya voennoplennykh [Journal of Meetings of the Astrakhan City Duma of November 13, 1918 on the Reservation of N.V. Serin's House for a Hospital for War Prisoners in the 4th District of Kutum]. Gosudarstvennyy arkhiv Astrakhanskoy oblasti [State Archive of the Astrakhan Region], F. 480, Op. 3, D. 345.

11. Kotenkov S.A., Kotenkova O.Yu. Potrebitelskaya kooperatsiya Astrakhanskogo kraya v gody Pervoy mirovoy voyny [Consumers' Cooperation in the Astrakhan Region During the First World War]. Kurapov A.A., ed. Astrakhanskie kraevedcheskie chteniya: sb. st. [Astrakhan Readings on Local History: Collection of Articles]. Astrakhan, Izd-vo Sorokina R.V., 2011, pp. 223-228.

12. Otchet Vrachebnogo otdela Astrakhanskogo gubernskogo pravleniya ot 28 marta $1916 \mathrm{~g}$. [Report of the Medical Department of the Astrakhan Provincial
Board of March 28, 1916]. Tragediya plena v mirovykh voynakh: politiko-pravovye, sotsialno-ekonomicheskie, kulturno-kommunikatsionnye aspekty (na materialakh Astrakhanskogo regiona): Sb. st. i dok. Ch. 1. [The Tragedy of Captivity in the World Wars: Political-Legal, Socio-Economic, Cultural and Communication Aspects (the Case of the Astrakhan Region): Collection of Articles and Documents. Part 1]. Astrakhan, Izd-vo Sorokina R.V., 2015.

13. Perepiska Astrakhanskogo gubernskogo zhandarmskogo upravleniya s Astrakhanskim grazhdanskim gubernatorom o voennoobyazannykh i voennoplennykh, prozhivayushchikh v g. Astrakhani [Correspondence of the Astrakhan Provincial Gendarmerie with the Astrakhan Civil Governor of Conscripts and Prisoners of War Living in the City of Astrakhan]. Gosudarstvennyy arkhiv Astrakhanskoy oblasti [State Archive of the Astrakhan Region], F. 286, Op. 1, D. 944.

14. Perepiska Astrakhanskoy gorodskoy upravy s Astrakhanskim grazhdanskim gubernatorom o prisylke voennoplennykh dlya provedeniya kanalizatsionnykh rabot [Correspondence of the Astrakhan City Council with Astrakhan Civil Governor on Dispatch of War Prisoners for Carrying Out Sewage Works]. Gosudarstvennyy arkhiv Astrakhanskoy oblasti [State Archive of the Astrakhan Region], F. 94, Op. 8, D. 569.

15. Perepiska Astrakhanskoy gorodskoy upravy s Astrakhanskim grazhdanskim gubernatorom po voprosu privlecheniya voennoplennykh k gorodskim rabotam [Correspondence of the Astrakhan City Council with Astrakhan Civil Governor on Engaging War Prisoners in the City Works]. Gosudarstvennyy arkhiv Astrakhanskoy oblasti [State Archive of the Astrakhan Region], F. 94, Op. 1, T. 4, D. 31172.

16. Perepiska Astrakhanskoy gorodskoy upravy s Astrakhanskim grazhdanskim gubernatorom po voprosu privlecheniya voennoplennykh $\mathrm{k}$ rabotam na gorodskoy elektrostantsii [Correspondence of the Astrakhan City Council with Astrakhan Civil Governor on Engaging War Prisoners in the Works at the City Power Plant]. Gosudarstvennyy arkhiv Astrakhanskoy oblasti [State Archive of the Astrakhan Region], F. 94, Op. 1, T. 4, D. 30814.

17. Perepiska Astrakhanskoy gubernskoy kantselyarii s Astrakhanskoy gorodskoy upravoy po voprosu ustroystva voennoplennykh i ikh imushchestva [The Correspondence of the Astrakhan Provincial Office with the Astrakhan City Council on Accommodation of War Prisoners and Their Property] Gosudarstvennyy arkhiv Astrakhanskoy oblasti [State Archive of the Astrakhan Region], F. 396, Op. 1, D. 3690 .

18. Perepiska Kantselyarii astrakhanskogo grazhdanskogo gubernatora s Astrakhanskoy 
gorodskoy upravoy po voprosu ustroystva voennoplennykh [Correspondence of the Office of Astrakhan Civil Governor with the Astrakhan City Council on the Issue of War Prisoners' Accommodation]. Gosudarstvennyy arkhiv Astrakhanskoy oblasti [State Archive of the Astrakhan Region], F. 1, Op. 2, D. 1495.

19. Perepiska Upravleniya astrakhanskogo uezdnogo voinskogo nachalnika s Astrakhanskim grazhdanskim gubernatorom o polozhenii voennoplennykh [Correspondence of the Administration of Astrakhan District Military Commander with Astrakhan Civil Governor on the Status of War Prisoners]. Gosudarstvennyy arkhiv Astrakhanskoy oblasti [State Archive of the Astrakhan Region], F. 700, Op. 1, D. 114, L. 113.

20. Raporty i vedomosti o kolichestve plennykh, nakhodyashchikhsya na rabotakh v voennykh okrugakh [Reports and Statements about the Number of Prisoners at Work in the Military Districts]. Gosudarstvennyy arkhiv Rossiyskoy Federatsii [State Archive of the Russian Federation], F. 3333, Op. 9, D. 1.

21. Svedeniya ob okazanii pomoshchi bezhentsam i litsam, postradavshim ot voennykh deystviy [Information on Assistance to Refugees and Persons Affected by Military Actions]. Gosudarstvennyy arkhiv Astrakhanskoy oblasti [State Archive of the Astrakhan Region], F. 1, Op. 2, D. 1437.

22. Semenov V.G., Yagudin I.R. Voennoplennye na territorii Kazanskogo voennogo okruga i Orenburgskoy gubernii na nachalnom etape Pervoy mirovoy voyny (po prikazam po Kazanskomu voennomu okrugu za 1914-1915 gg.) [Prisoners of War on the Territory of the Kazan Military District and the Orenburg Province at the Initial Stage of the First World War (by the Orders of the Kazan Military District for 1914-1915)]. Evraziyskoe ozherelye: almanakh Obshchestvennogo instituta istorii narodov Orenburzhya imeni Musy Dzhalilya. Vyp. 6 [Eurasian Necklace: Almanac of the Public Institute of History of Peoples of the Orenburg Region named after Musa Dzhalil. Iss. 6]. Orenburg, Izd-vo OGPU, 2005, pp. 91-110.

23. Semenova E.Yu. Mirovozzrenie gorodskogo naseleniya Povolzhya v gody Pervoy mirovoy voyny (1914 - nachalo 1918 gg.): sotsialnyy, ekonomicheskiy i politicheskiy aspekty [Outlook of the Urban Population of the Volga Region in the Years of the First World War (1914 - Early 1918): Social, Economic and Political Aspects]. Samara, Izd-vo SNTs RAN, 2012. 888 p.

24. Spiski voennoplennykh nizhnikh chinov avstriyskoy i germanskoy armiy [Lists of War Prisoners of Lower Ranks of the Austrian and German Armies]. Gosudarstvennyy arkhiv Astrakhanskoy oblasti [State Archive of the Astrakhan Region], F. 700, Op. 2, D. 157.
25. Spravka o voennoplennykh i voennoobyazannykh za $1916 \mathrm{~g}$. [Reference about War Prisoners and Military Servants for 1916]. Gosudarstvennyy arkhiv Astrakhanskoy oblasti [State Archive of the Astrakhan Region], F. 286, Op. 1, D. 944.

26. Tabel na vydachu zhalovanya voennoplennym, rabotavshim na kanalizatsionnykh rabotakh [Report Card on the Issuance of Salaries to War Prisoners Engaged in Sewage Works]. Gosudarstvennyy arkhiv Astrakhanskoy oblasti [State Archive of the Astrakhan Region], F. 94, Op. 8, D. 873.

27. Telegrammy o predostavlenii vagonov dlya perevozki bezhentsev, voennoplennykh [Telegrams on the Provision of Wagons for Transportation of Refugees and War Prisoners]. Gosudarstvennyy arkhiv Rossiyskoy Federatsii [State Archive of the Russian Federation], F. 3333, Op. 4, D. 107.

28. Timofeeva, E.G. Astrakhan v sobytiyakh Velikoy voyny, 1914-1918 gody [Astrakhan in the Events of the Great War, 1914-1918]. Astrakhan, Nova Publ., 2014. 300 p.

29. Timofeeva E.G., Fedin S.A., Lebedev S.V. Ispolzovanie truda inostrannykh voennoplennykh $\mathrm{V}$ period Pervoy mirovoy voyny (na materialakh Astrakhanskoy gubernii) [Employment of Foreign War Prisoners During the First World War (on the Materials of the Astrakhan Province)]. Tragediya plena $v$ mirovykh voynakh: politiko-pravovye, sotsialnoekonomicheskie, kulturno-kommunikatsionnye aspekty (na materialakh Astrakhanskogo regiona): Sb. st. i dok. Ch. 1. [The Tragedy of Captivity in the World Wars: Political-Legal, Socio-Economic, Cultural and Communication Aspects (the Case of the Astrakhan Region): Collection of Articles and Documents. Part 1]. Astrakhan, Izd-vo Sorokina R.V., 2015, pp. 61-72.

30. Timofeeva E.G., Lebedev S.V. Organizatsiya mediko-sanitarnoy pomoshchi voennoplennym mirovykh voyn v Astrakhanskom krae [Organization of Health Care to War Prisoners of World Wars in the Astrakhan Region]. Izvestiya VGPU [Bulletin of VGPU], 2016, no. 9-10(113), pp. 187-193.

31. Tyurin A.O. Okhrana i nadzor za voennoplennymi v Astrakhanskom krae v gody mirovykh voyn [Guard and Supervision on War Prisoners in the Astrakhan Region in the Years of World Wars]. Izvestiya VGPU [Bulletin of VGPU], 2016, no. 9-10(113), pp. 179-187.

32. Fedin S.A., Timofeeva E.G. Soderzhanie i okhrana voennoplennykh: opyt mirovykh voyn (na materialakh Astrakhanskogo regiona) [Accomodation and Protection of War Prisoners: the Experience of World Wars (on Materials of the Astrakhan Region)]. Izvestiya VGPU[Bulletin of VGPU], 2015, no. 6(101), pp. 186-192.

33. Tsirkulyary Astrakhanskogo gubernskogo komissara za 1917 g. [Circulars of the Astrakhan Provincial Commissioner for 1917]. Gosudarstvennyy 
Е.Г. Тимофеева, С.В. Лебедев, Е.Ю. Болотова. Иностранные военнопленные на территории Астраханской губ.

arkhiv Astrakhanskoy oblasti [State Archive of the Astrakhan Region], F. 290, Op. 3, D. 882.

34. Tsirkulyary Glavnogo upravleniya po delam mestnogo khozyaystva o ispolzovanii voennoplennykh
[Circulars of the Main Directorate of the Local Economy on the Use of War Prisoners]. Gosudarstvennyy arkhiv Astrakhanskoy oblasti [State Archive of the Astrakhan Region], F. 94, Op. 1, T. 8, D. 35454.

\section{Information about the Authors}

Elena G. Timofeeva, Doctor of Sciences (History), Professor, Dean of Faculty of History, Astrakhan State University, Tatishcheva St., 20a, 414056 Astrakhan, Russian Federation, timofeeva.asu@mail.ru, https://orcid.org/0000-0002-7761-3812

Sergey V. Lebedev, Candidate of Sciences (History), Associate Professor, Department of History of Russia, Astrakhan State University, Tatishcheva St., 20a, 414056 Astrakhan, Russian Federation, dnsv@mail.ru, https://orcid.org/0000-0002-0619-6169

Elena Yu. Bolotova, Doctor of Sciences (History), Professor, Head of Department of Russian History and Local History Education, Dean of Faculty of Historical and Legal Education, Volgograd State Socio-Pedagogical University, Prosp. Lenina, 27, 400066 Volgograd, Russian Federation, eubolotova@yandex.ru, https://orcid.org/0000-0001-6432-2373

\section{Информация об авторах}

Елена Георгиевна Тимофеева, доктор исторических наук, профессор, декан исторического факультета, Астраханский государственный университет, ул. Татищева, 20a, 414056 г. Астрахань, Российская Федерация, timofeeva.asu@mail.ru, https://orcid.org/0000-0002-7761-3812

Сергей Владиславович Лебедев, кандидат исторических наук, доцент кафедры истории России, Астраханский государственный университет, ул. Татищева, 20a, 414056 г. Астрахань, Российская Федерация, dnsv@mail.ru, https://orcid.org/0000-0002-0619-6169

Елена Юрьевна Болотова, доктор исторических наук, профессор, заведующая кафедрой отечественной истории и историко-краеведческого образования, декан факультета исторического и правового образования, Волгоградский государственный социально-педагогический университет, просп. Ленина, 27, 400066 г. Волгоград, Российская Федерация, eubolotova@yandex.ru, https://orcid.org/0000-0001-6432-2373 